\title{
Time course analysis of gene regulation under cadmium stress in rice
}

\author{
Ippei Ogawa $\cdot$ Hiromi Nakanishi $\cdot$ Satoshi Mori • \\ Naoko K. Nishizawa
}

Received: 19 February 2009 / Accepted: 15 July 2009/Published online: 4 August 2009

(C) The Author(s) 2009. This article is published with open access at Springerlink.com

\begin{abstract}
To elucidate the regulation of gene expression in response to cadmium (Cd) stress in rice (Oryza sativa), transcriptional changes in roots and shoots were investigated using a $22 \mathrm{~K}$ microarray covering 21,495 genes. Rice plants were exposed to $10 \mu \mathrm{M} \mathrm{CdCl}_{2}$ for $3 \mathrm{~h}$ or $1 \mu \mathrm{M} \mathrm{CdCl}_{2}$ for 24,48 , and $72 \mathrm{~h}$, and 8 days in hydroponic culture. In roots, 1,207 genes were up-regulated, whereas 519 genes were down-regulated by more than twofold under $10 \mu \mathrm{M} \mathrm{Cd}$ stress for $3 \mathrm{~h}$. Compared with roots, the shoots had fewer Cd-responsive genes. The expression of genes such as those encoding cytochrome P450 family proteins, heat shock proteins, and glutathione S-transferase was strongly induced. Genes encoding proteins involved in signal transduction, including transcription factors such as DREB and NAC, and protein kinases, were also induced. Genes involved in photosynthesis were mainly downregulated after $3 \mathrm{~h}$ of stress. Genes for the synthesis of nicotianamine and 2'-deoxymugineic acid were
\end{abstract}

Responsible Editor: Jian Feng Ma.

Electronic supplementary material The online version of this article (doi:10.1007/s11104-009-0116-9) contains

supplementary material, which is available to authorized users.

I. Ogawa $\cdot$ H. Nakanishi $(\bowtie) \cdot S$. Mori $\cdot$ N. K. Nishizawa Graduate School of Agricultural and Life Sciences,

The University of Tokyo,

1-1 Yayoi, Bunkyo-ku,

Tokyo 113-8657, Japan

e-mail: ahnaka@mail.ecc.u-tokyo.ac.jp induced in roots under $1 \mu \mathrm{M} \mathrm{Cd}$ stress for 8 days, suggesting the occurrence of iron deficiency under longer-term Cd stress. Cd-regulated transporter genes included PDR and MATE family transporters, which were strongly up-regulated in roots, especially under $10 \mu \mathrm{M} \mathrm{Cd}$ stress, suggesting their role in $\mathrm{Cd}$ detoxification via export of $\mathrm{Cd}$ from the cytoplasm. Their modification may potentially lead to the development of low-Cd rice, which contributes to human health as well as high-Cd rice useful for phytoremediation.

Keywords Cadmium · Rice · Microarray · Gene regulation

\section{Introduction}

In recent years, accumulation of cadmium $(\mathrm{Cd})$ in crop plants has become a major threat to agriculture and human health. Many of the world's areas of arable soils have become moderately contaminated with $\mathrm{Cd}$ through the use of phosphate fertilizers, sludge, and irrigation water containing $\mathrm{Cd}$ (Sanità di Toppi and Gabbrielli 1999; McGrath et al. 2001; Kikuchi et al. 2007). Considerable Cd accumulation in edible parts of crops, including rice, occurs in these areas (Arao and Ae 2003; Arao et al. 2003; Ishikawa et al. 2005). Cd causes toxic effects on all living organisms, and humans are at risk because it enters our bodies through the food chain. Crop plants uptake 
Cd from soil and accumulate it in the edible parts ingested by humans or domesticated animals. Generally, higher concentrations of $\mathrm{Cd}$ in the soil result in higher concentrations of $\mathrm{Cd}$ in the plant body, and phytoremediation is one solution to this problem. Milyang 23 was selected as a promising cultivar of rice for the phytoextraction of $\mathrm{Cd}$ in paddy soils (Murakami et al. 2008). Breeding or biotechnology may provide effective methods for either producing food plants with low $\mathrm{Cd}$ content or sequestering $\mathrm{Cd}$ for phytoremediation; however, little is known about the molecular mechanisms of $\mathrm{Cd}$ distribution in the plant body or the response to $\mathrm{Cd}$ stress.

$\mathrm{Cd}$ has been reported to cause oxidative stress in cells (Sandalio et al. 2001; Romero-Puertas et al. 2004), although the details of the stress mechanism are still largely unknown. Unlike iron $(\mathrm{Fe})$ or copper $(\mathrm{Cu}), \mathrm{Cd}$ does not directly catalyze the generation of reactive oxygen species (ROS). Cd-caused toxicity has been reported to result from a disturbance in the balance of essential metals such as $\mathrm{Fe}$ and $\mathrm{Cu}$ in metalloenzymes (Stohs and Bagchi 1995).

Some genes and/or proteins regulated by excess $\mathrm{Cd}$ have been identified from transcription and proteomic analyses of Arabidopsis thaliana (Suzuki et al. 2001; Herbette et al. 2006; Sarry et al. 2006) and Indian mustard (Brassica juncea) (Fusco et al. 2005). One well-characterized mechanism of $\mathrm{Cd}$ detoxification is the chelation of $\mathrm{Cd}$ by glutathione (GSH) or phytochelatins (PCs) and the sequestration of the complexes in locations where their effects are less toxic (Grill et al. 1985; Howden et al. 1995a, b; Cobbett et al. 1998). In yeast, glutathioneconjugated $\mathrm{Cd}$ (GS-Cd) is sequestered in the vacuole by export from the cytoplasm via a glutathioneconjugated complex (GS-X)-transporting protein localized at the tonoplast ( $\mathrm{Li}$ et al. 1997). Metallothioneins, which are gene-encoded peptides, also form complexes with heavy metals and are involved in detoxification or translocation (Clemens et al. 2002; Benavides et al. 2005). In Arabidopsis, rootto-shoot or shoot-to-root translocation of PCs, mostly via phloem, has been reported, suggesting that long-distance $\mathrm{Cd}$ translocation between the root and shoot is mediated by PCs (Gong et al. 2003).

Thlaspi caerulescens and Arabidopsis halleri are able to accumulate zinc ( $\mathrm{Zn})$ and $\mathrm{Cd}$ at high concentrations and are thus referred to as hyperaccumulators (Robinson et al. 1998; Bert et al. 2000). In these plants, highly expressed $\mathrm{Zn}$ transporters such as the ZIP family transporters (Grotz et al. 1998) are involved in $\mathrm{Zn}$ influx into the cytoplasm (Pence et al. 2000). However, the mechanism of $\mathrm{Cd}$ uptake and accumulation has not been well defined in these hyperaccumulators. Often, Fe or $\mathrm{Zn}$ transporters, owing to their low substrate specificity, are also involved in $\mathrm{Cd}$ transport. Among the ZIP family of Arabidopsis and rice, AtIRT1, OsIRT1, and OsIRT2, which are Fe transporters, and OsZIP1, which is a $\mathrm{Zn}$ transporter, have been shown to transport $\mathrm{Cd}$ (Korshunova et al. 1999; Nakanishi et al. 2006). In the heavy metal P-type ATPase (HMA) family, one of the $\mathrm{P}_{1 \mathrm{~B}}$-ATPase family transporters is involved in $\mathrm{Cd}$ detoxification. Overexpression of these genes conferred $\mathrm{Cd}$ resistance and resulted in changes in the amount of $\mathrm{Cd}$ accumulated in the plant body (Gravot et al. 2004; Verret et al. 2004). Other ATPases, cation diffusion facilitator (CDF) transporters, and natural resistance-associated macrophage protein (NRAMP) family transporters have been reported to transport $\mathrm{Cd}$ (Thomine et al. 2000). Pleiotropic drug resistance (PDR) family proteins are involved in $\mathrm{Cd}$ tolerance via export out of the cytoplasm (Kim et al. 2007). Transporter genes in rice should be studied further to clarify $\mathrm{Cd}$ transport and tolerance mechanisms.

In this study, we focused on determining the candidate genes involved in $\mathrm{Cd}$ transport for detoxification or translocation and on the identification of the molecular determinant/signals/network regulating $\mathrm{Cd}$ stress in rice. Using an Agilent $22 \mathrm{~K}$ rice oligomicroarray kit (Agilent Technologies, Tokyo, Japan), we analyzed Cd-regulated stress-related genes in rice roots and shoots, as well as some of the metabolic pathways and transporters putatively involved in $\mathrm{Cd}$ translocation or tolerance. The results provide an overview of molecular responses to $\mathrm{Cd}$ stress and identify potential target genes that may contribute to the reduction of $\mathrm{Cd}$ content or may be useful for the accumulation of large amounts of $\mathrm{Cd}$ in rice for phytoremediation.

\section{Materials and methods}

Plant material

Rice (Oryza sativa var. japonica. cv. Nipponbare) was grown in 20-L plastic containers containing a nutrient 
solution with the following composition: $0.35 \mathrm{mM}$ $\left(\mathrm{NH}_{4}\right)_{2} \mathrm{SO}_{4}, 0.18 \mathrm{mM} \mathrm{Na} \mathrm{HPO}_{4}, 0.27 \mathrm{mM} \mathrm{K} \mathrm{SO}_{4}$, $0.36 \mathrm{mM} \mathrm{CaCl}_{2}, 0.46 \mathrm{mM} \mathrm{MgSO}_{4}, 18 \mu \mathrm{M} \mathrm{H}_{3} \mathrm{BO} 3$, $4.6 \mu \mathrm{M} \mathrm{MO_{4 }}, 1.5 \mu \mathrm{M} \mathrm{ZnSO}_{4}, 1.5 \mu \mathrm{M} \mathrm{CuSO}_{4}$, $1.0 \mu \mathrm{M} \mathrm{Na} \mathrm{MoO}_{4}$, and $45 \mu \mathrm{M}$ Fe(III)-EDTA. The solution was maintained at $\mathrm{pH} 5.0-5.5$ with $1 \mathrm{M}$ $\mathrm{KOH}$. After 24 days of growth, half of the plants were transferred to a nutrient solution containing $10 \mu \mathrm{M} \mathrm{CdSO}{ }_{4}$ and grown for $3 \mathrm{~h}$, or containing $1 \mu \mathrm{M} \mathrm{CdSO}_{4}$ and grown for $24 \mathrm{~h}, 48 \mathrm{~h}, 72 \mathrm{~h}$, or 8 days. The remaining plants were transferred to a nutrient solution without $\mathrm{Cd}$, as a control. At each time point, nine plants from Cd-treated and control groups respectively were harvested for microarray analysis.

\section{Oligo-DNA microarray analysis}

A rice $22 \mathrm{~K}$ oligo-DNA microarray (Agilent Technologies), which contains 21,495 oligonucleotides synthesized based on sequence data of the rice full-length cDNA project (http://cdna01.dna. affrc.go.jp/cDNA/), was used. Total RNA was prepared from whole roots or shoots using the RNeasy Plant Kit (Qiagen, Tokyo, Japan) according to the manufacturer's instructions. The yield and RNA purity were determined spectrophotometrically. The integrity of the RNA was checked using an Agilent 2100 Bioanalyzer, and total RNA (400 ng) was labeled with Cy-3 or Cy-5 using an Agilent Low RNA Input Fluorescent Linear Amplification Kit. To assess the reproducibility of the signals, the experiment was repeated by dye swapping. Fluorescently labeled targets were hybridized to Agilent rice $22 \mathrm{~K}$ oligo DNA microarrays. The hybridization process was performed according to the manufacturer's instructions, and hybridized microarrays were scanned using an Agilent Microarray Scanner. Feature Extraction software (Agilent Technologies) was used for image analysis and data extraction processes. The fold changes were calculated (signal intensity of Cd-treated plants/signal intensity of control plants) at each time point. Genes showing fold changes $>2$ or $<0.5$ and with $P$-values $<0.05$ were considered to be significantly up- or down-regulated, respectively. For clustering and imaging of the data, Cluster and Treeview (Eisen lab; http://rana.lbl.gov/) were used.

\section{Results}

Shoot growth was inhibited and chlorophyll content (SPAD value) of the largest leaves did not increase after the addition of either $1 \mu \mathrm{M}$ or $10 \mu \mathrm{M} \mathrm{Cd}$ (Fig. 1). After 2 days of $\mathrm{Cd}$ exposure, growth was significantly inhibited. The growth inhibition by $\mathrm{Cd}$ was nearly identical at both concentrations.

The number of genes whose expression was changed by $\mathrm{Cd}$ stress was analyzed (Fig. 2). In the case of treatment with $10 \mu \mathrm{M}$ of $\mathrm{Cd}$ for $3 \mathrm{~h}, 1,207$ (in roots, $5.6 \%$ of the total) and 211 (in shoots, $1.0 \%$ ) genes were up-regulated by $\mathrm{Cd}$. Under the same conditions 519 (in roots, 2.4\%) and 375 (in shoots, $1.7 \%$ ) genes were down-regulated by more than twofold. When rice was exposed to the lower concentration $(1 \mu \mathrm{M})$ for $24 \mathrm{~h}, 48 \mathrm{~h}, 72 \mathrm{~h}$, and 8 days, the number of Cd-regulated genes was much lower than that for $10 \mu \mathrm{M} \mathrm{Cd}$. It seems that dramatic changes in the level of gene expression occurred in the roots exposed to $10 \mu \mathrm{M} \mathrm{Cd}$ for $3 \mathrm{~h}$. In roots, the number of up-regulated genes was always greater than the number down-regulated, although this was not true in the shoots. The number of genes regulated in roots was larger than that regulated in the corresponding shoots except when exposed to $1 \mu \mathrm{M}$ $\mathrm{Cd}$ for 8 days. In shoots exposed to $1 \mu \mathrm{M} \mathrm{Cd}$ for 24-72 $\mathrm{h}$, changes in the expression of only a few genes were greater than twofold. This suggested that the shoot is less affected by $\mathrm{Cd}$ stress than the roots, although an early response to $\mathrm{Cd}$ at $24 \mathrm{~h}$ and possibly a secondary effect of $\mathrm{Cd}$ after 8 days of treatment appeared to exist.

When Cd-regulated genes showing the most dramatic regulation are ordered according to their relative change in expression in roots exposed to $10 \mu \mathrm{M} \mathrm{Cd}$ for $3 \mathrm{~h}$, the top 50 up-regulated genes (Table 1) comprise six zinc-finger domain-containing protein genes including a ZIM domain-containing protein gene and a ZPT2-14 gene, three heat shock protein or precursor genes, three cytochrome $\mathrm{P} 450$ family protein genes, OsDREB1A, OsDREB1B, an MYB domain protein gene, a NAC domain-containing protein gene, an AP2 domain-containing protein, a WRKY transcription factor gene, glutathione S-transferase (GST) gene, genes for enzymes such as isocitrate lyase and allene oxide synthase, which are related to specific metabolic pathways, and some genes for transporter proteins such as the PDR transporter and the 
Fig. 1 Changes in shoot length and chlorophyll content of rice before/after Cd stress treatment. a Shoot length. b Chlorophyll content measured as the soil plant analysis development (SPAD) value. Control (blue), $1 \mu \mathrm{M} \mathrm{Cd}$ (orange), $10 \mu \mathrm{M} \mathrm{Cd}($ red $)$. Arrows show the addition of $\mathrm{Cd}$. $n=3$ (after Cd treatment) or 5 (before Cd treatment). Significant differences compared with controls were analyzed using a $t$-test $(*, P<0.05)$. Error bars indicate $\mathrm{SD}$

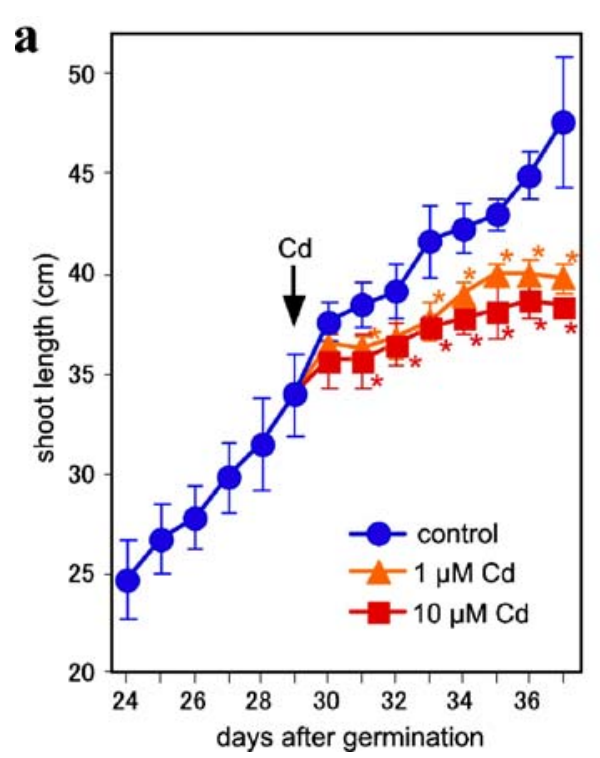

multidrug and toxin extrusion (MATE) family proteins.

\section{Discussion}

Significantly regulated genes and their possible functions in Cd stress

The inhibition of shoot growth by treatment with both $1 \mu \mathrm{M}$ and $10 \mu \mathrm{M}$ Cd demonstrated nearly equivalent

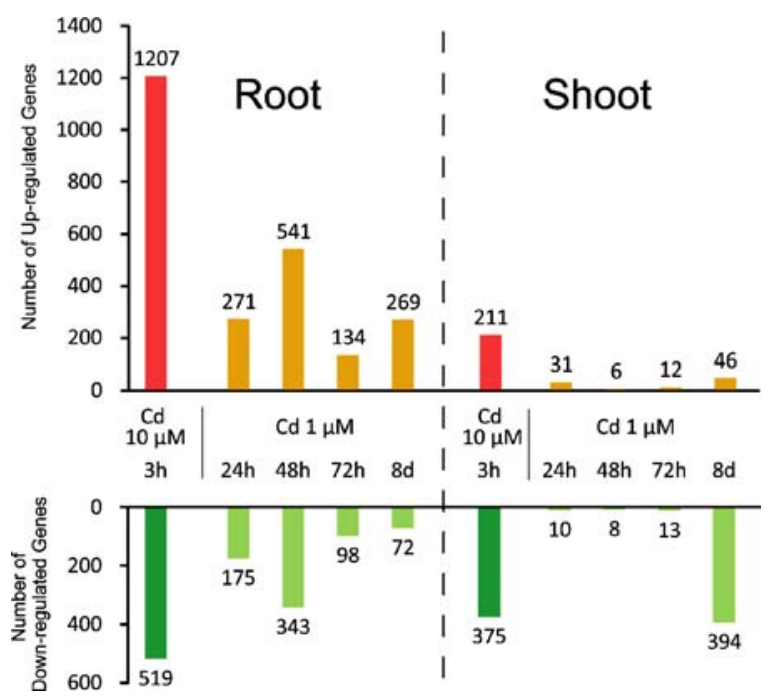

Fig. 2 The number of genes up- or down-regulated by Cd by more than twofold under each set of conditions $(P<0.05)$

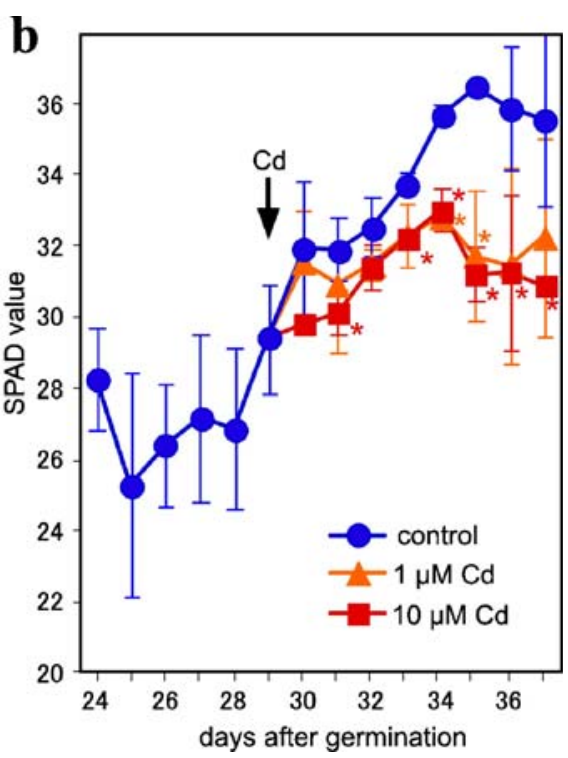

trends (Fig. 1); however, 3-h treatment with $10 \mu \mathrm{M}$ $\mathrm{Cd}$ induced a greater number of genes than did 24-h treatment with $1 \mu \mathrm{M}$ Cd (Fig. 2). Table 1 lists the Cd-regulated genes showing the most dramatic regulation. The strong induction by $\mathrm{Cd}$ in a short time was confirmed by semi-quantitative reverse transcription PCR using the different plant samples from those used for microarray (Supplemental Fig. 1). The upregulation of heat shock protein genes was consistent with other organisms such as yeast (Momose and Iwahashi 2001; Vido et al. 2001) and Arabidopsis (Vierling 1991; Sarry et al. 2006). Protein misfolding caused by Cd stress may have led to the induction of heat shock proteins. P450 enzymes have a wide spectrum of enzymatic activities; they are able to metabolize many xenobiotics and one of their orthologs in Drosophila was also up-regulated by Cd stress (Yepiskoposyan et al. 2006). GST catalyzes the conjugation of GSH to a variety of harmful compounds. Involvement of these genes, along with the P450 enzymes, in the $\mathrm{Cd}$ response was also observed in Drosophila, suggesting that involvement of P450 enzymes and GSTs are a well-conserved mechanism of the $\mathrm{Cd}$ response in a wide range of organisms. Transcription factors OsDREB1A and OsDREB1B have been reported to respond to cold stress and salt stress, and their constitutive overexpression in plants resulted in tolerance to freezing and high-salt (Dubouzet et al. 2003). Other transcription factors such as NAC proteins have been reported 
Table 1 The 50 genes with the greatest relative expression in roots of $10 \mu \mathrm{M}$ Cd-treated $(3 \mathrm{~h})$ plants

\begin{tabular}{|c|c|c|c|}
\hline & Gene location & RAP-DB description & Fold Change \\
\hline 1 & Os01g0373700 & Conserved hypothetical protein & 62.68 \\
\hline 2 & Os03g0180900 a & ZIM domain containing protein & 52.15 \\
\hline 3 & Os01g0699600 & Protein kinase-like domain containing protein & 44.16 \\
\hline 4 & Os03g0820300 a & Similar to ZPT2-14 & 43.27 \\
\hline 5 & Os01g0389700 & Protein of unknown function DUF679 family protein & 40.16 \\
\hline 6 & Os $10 \mathrm{~g} 0517500^{\mathrm{a}}$ & Cys/Met metabolism pyridoxal-phosphate-dependent enzymes family protein & 37.59 \\
\hline 7 & Os01g0373800 & Conserved hypothetical protein & 35.63 \\
\hline 8 & Os01g0609300 a & OsPDR9 & 34.85 \\
\hline 9 & Os11g0151400 & Cytochrome P450 family protein & 32.61 \\
\hline 10 & Os07g0529000 & Similar to Isocitrate lyase (Fragment) & 30.12 \\
\hline 11 & Os10g0392400 & ZIM domain containing protein & 28.78 \\
\hline 12 & Os01g0661800 & Conserved hypothetical protein & 28.72 \\
\hline 13 & Os09g0243200 & Zinc finger, RING-type domain containing protein & 28.59 \\
\hline 14 & Os03g $0437200^{\mathrm{a}}$ & Zinc finger, $\mathrm{C} 2 \mathrm{H} 2$-type domain containing protein & 27.96 \\
\hline 15 & Os03g0760200 & Cytochrome P450 family protein & 27.73 \\
\hline 16 & Os08g0120600 & Similar to fructose-bisphosphate aldolase, cytoplasmic isozyme (EC 4.1.2.13) & 27.07 \\
\hline 17 & Os09g0367700 & OsGSTU5 & 25.49 \\
\hline 18 & Os02g0758000 & Similar to low molecular weight heat shock protein precursor & 23.78 \\
\hline 19 & Os01g0952900 & Conserved hypothetical protein & 23.56 \\
\hline 20 & Os04g0419100 & Conserved hypothetical protein & 23.28 \\
\hline 21 & Os04g0405300 & Similar to Stem secoisolariciresinol dehydrogenase (Fragment) & 23.07 \\
\hline 22 & Os09g $0522000^{\mathrm{a}}$ & OsDREB1B & 22.26 \\
\hline 23 & Os12g0564100 & Similar to R2R3MYB-domain protein (Fragment) & 22.04 \\
\hline 24 & Os01g0816100 & Similar to NAC domain protein & 21.43 \\
\hline 25 & Os04g0180400a & Similar to cytochrome P450 CYP99A1 (EC 1.14.-.-) (Fragment) & 21.27 \\
\hline 26 & Os04g0107900 a & Similar to heat shock protein 80 & 21.09 \\
\hline 27 & Os07g0605800 & Similar to STF-1 (Fragment) & 19.94 \\
\hline 28 & Os01g0106900 & Similar to 1-deoxy-D-xylulose 5-phosphate reductoisomerase (Fragment) & 19.82 \\
\hline 29 & Os09g0522200 & OsDREB1A & 19.13 \\
\hline 30 & Os04g0339400 & Aldo/keto reductase family protein & 18.73 \\
\hline 31 & Os03g0676400 & VQ domain containing protein & 18.50 \\
\hline 32 & Os $10 \mathrm{~g} 0345100^{\mathrm{a}}$ & Multi antimicrobial extrusion protein MatE family protein & 18.22 \\
\hline 33 & Os09g0385700 & Zinc finger, AN1-type domain containing protein & 18.06 \\
\hline 34 & Os07g0550600 & Transferase family protein & 17.95 \\
\hline 35 & Os08g0140300 & Similar to tryptophan decarboxylase & 17.80 \\
\hline 36 & Os08g0474000 & Similar to AP2 domain containing protein RAP2.6 (Fragment) & 17.69 \\
\hline 37 & Os07g0638100 & TolB, C-terminal domain containing protein & 17.61 \\
\hline 38 & Os02g0181300 & WRKY transcription factor 71 (Transcription factor WRKY09) & 17.52 \\
\hline 39 & Os01g0639600 & Protein of unknown function DUF1645 family protein & 17.43 \\
\hline 40 & Os11g0643100 & Transferase family protein & 17.32 \\
\hline 41 & Os03g0225900 a & Allene oxide synthase & 17.19 \\
\hline 42 & Os01g0699500 & Protein kinase-like domain containing protein & 17.00 \\
\hline 43 & Os07g0526600 & Esterase/lipase/thioesterase domain containing protein & 16.75 \\
\hline 44 & Os01g0172100 & Similar to triose phosphate/phosphate translocator & 16.20 \\
\hline
\end{tabular}


Table 1 (continued)

\begin{tabular}{llll}
\hline & Gene location & RAP-DB description & Fold Change \\
\hline 45 & Os10g0370500 & Actin-crosslinking proteins family protein & 16.15 \\
46 & Os04g0516600 & Aromatic amino acid beta-eliminating lyase/threonine aldolase domain containing protein & 15.76 \\
47 & Os06g0586000 & Conserved hypothetical protein & 15.74 \\
48 & Os11g0244200 & Similar to pisum sativum 17.9 kDa heat shock protein (hsp17.9) (Fragment) & 15.30 \\
49 & Os06g0215600 & Similar to oxo-phytodienoic acid reductase & 15.24 \\
50 & Os01g0510200 & Conserved hypothetical protein & 15.16 \\
\hline
\end{tabular}

${ }^{a}$ Induction by Cd was confirmed by semi-quantitative reverse transcription PCR (Supplemental Fig. 1)

to mediate viral resistance (Xie et al. 1999) or to be involved in abiotic stress responses and tolerance by responding to drought, high salinity, abscisic acid (ABA), and methyl jasmonic acid (Fujita et al. 2004). Although the involvement of these transcription factors in response to $\mathrm{Cd}$ has not been previously documented, the novel finding that these are also upregulated by $\mathrm{Cd}$ suggests a common responsive pathway between $\mathrm{Cd}$ and other abiotic stresses.

Up-regulated transporters with a possible involvement in $\mathrm{Cd}$ transport in roots

Analyzing Cd-regulated transporter genes is important because their modification may affect the level of accumulation of substrates, which can then be applied to bioengineering of crops with either significantly lesser or greater amounts of $\mathrm{Cd}$, which is advantageous for food or phytoremediation, respectively. Most of the Cd-regulated transporters were affected within 3-48 h of $\mathrm{Cd}$ stress, suggesting that these transporters are affected relatively rapidly by $\mathrm{Cd}$ (Table 2). These include genes belonging to transporter families such as the $\mathrm{ABC}$ transporter superfamily [PDR, MDR, and multidrug resistance protein (MRP) subfamilies] and the MATE, CDF, HMA, and ZIP families. PDR, MDR, MRP, MATE, CDF, and HMA all have a high possibility of involvement in export of $\mathrm{Cd}$ from the cytoplasm because some orthologs of these transporters have been reported to be involved in $\mathrm{Cd}$ transport or detoxification activities (Li et al. 2002; Gravot et al. 2004; Verret et al. 2004; Kim et al. 2007). For example, one of the PDR transporters in Arabidopsis, AtPDR8, whose expression is up-regulated by $\mathrm{Cd}$ or $\mathrm{Pb}$, is a $\mathrm{Cd} / \mathrm{Pb}$ extrusion pump conferring tolerance to these metals (Kim et al. 2007). AtPDR8 is localized to the plasma membrane primarily in the root hair and epidermal cells. AtPDR8-over-expressing plants have lower Cd contents than the wild type, and plants whose AtPDR8 function is mutated by RNAi or T-DNA show lower $\mathrm{Cd}$ contents. As for the MDR proteins, both the human and bacterial MDR genes confer Cd resistance to E. coli by extruding Cd (Achard-Joris et al. 2005). One of the MRP proteins in yeast, YCF1, confers $\mathrm{Cd}$ tolerance by transporting $(\mathrm{GSH})_{2}-\mathrm{Cd}^{2+}$ complexes to vacuoles, which have a low metabolic activity, resulting in a greater capacity to accumulate toxic compounds (Li et al. 1997). One of the MRP proteins in Arabidopsis, AtMRP3, whose gene expression was up-regulated by Cd treatment (Bovet et al. 2003), has been reported to partially restore the $\mathrm{Cd}$ resistance of a complemented $y c f 1$ yeast mutant (Tommasini et al. 1998). One of the MATE proteins in Arabidopsis, AtDTX1, confers Cd tolerance to the drug-sensitive E. coli mutant strain KAM3 (Li et al. 2002). One of the CDF proteins in Bacillus subtilis, $\mathrm{CzcD}$, is involved in the efflux of $\mathrm{Zn}, \mathrm{Cd}$, and Co. Some HMA proteins in Arabidopsis have been reported to be involved in Cd tolerance, accumulation, and rootto-shoot translocation via export of $\mathrm{Cd}$ from the cytoplasm (Eren and Argüello 2004; Gravot et al. 2004; Verret et al. 2004; Mills et al. 2005). An upregulated ZIP family transporter, OsIRT1, is an Fe importer that has been reported to also transport $\mathrm{Cd}$ (Nakanishi et al. 2006). Further investigation is needed to explain its role in the response to $\mathrm{Cd}$.

Cluster analysis revealed time-dependent regulation of responsive genes

We performed clustering of the 3,596 genes shown in Fig. 2 (genes that were up- or down-regulated by more than twofold under at least one of the 
Table 2 Transporter genes possibly involved in the Cd stress response whose expression was induced or reduced under Cd stress in roots

\begin{tabular}{|c|c|c|c|c|c|c|}
\hline \multirow[t]{3}{*}{ Gene location } & \multirow[t]{3}{*}{ Gene product } & \multicolumn{5}{|c|}{ Fold change (Root) ${ }^{\mathrm{a}}$} \\
\hline & & \multirow{2}{*}{$\begin{array}{l}10 \mu \mathrm{M} \mathrm{Cd} \\
3 \mathrm{~h}\end{array}$} & \multicolumn{4}{|c|}{$1 \mu \mathrm{M} \mathrm{Cd}$} \\
\hline & & & $24 \mathrm{~h}$ & $48 \mathrm{~h}$ & $72 \mathrm{~h}$ & $8 \mathrm{~d}$ \\
\hline Os01g0609300 & OsPDR9 & 34.9 & 1.8 & 2.0 & 1.0 & $\overline{0.5}$ \\
\hline Os08g0544400 & OsPDR1 & 9.7 & 2.2 & 4.7 & 1.4 & 1.6 \\
\hline Os $08 \mathrm{~g} 0384500^{\mathrm{b}}$ & OsPDR17 & 7.5 & 1.6 & 0.9 & 1.2 & 0.9 \\
\hline Os07g0522500 & OsPDR5 & 6.0 & 1.8 & 1.4 & 1.0 & 1.0 \\
\hline Os01g0609900 & OsPDR8 & 2.8 & 1.4 & 1.8 & 1.0 & 0.6 \\
\hline Os01g0342700 & OsPDR16 & 2.0 & 1.4 & 1.6 & 1.3 & 0.9 \\
\hline Os01g0695800 & MDR & 4.6 & 1.6 & 1.7 & 1.2 & 1.0 \\
\hline Os04g0209200 & MRP & 3.6 & 1.2 & 1.2 & 1.1 & 0.8 \\
\hline Os $10 \mathrm{~g} 0345100^{\mathrm{b}}$ & MATE efflux family protein & 18.2 & 1.9 & 0.4 & 0.9 & 1.2 \\
\hline Os10g0190900 & MATE efflux family protein & 3.5 & 1.0 & 0.8 & 0.8 & 1.2 \\
\hline Os01g0504500 & MATE efflux family protein & 2.9 & 1.4 & 1.1 & 1.1 & 1.2 \\
\hline Os01g0684900 & MATE efflux family protein & 2.4 & 1.0 & 1.0 & 1.0 & 0.9 \\
\hline Os01g0837800 & $\mathrm{CDF}$ & 2.0 & 1.3 & 1.2 & 0.9 & 0.9 \\
\hline Os04g0556000 & OsHMA5 & 2.0 & 1.2 & 1.4 & 1.0 & 1.2 \\
\hline Os03g0667500 & OsIRT1 & 2.2 & 1.2 & 1.3 & 1.2 & 1.8 \\
\hline
\end{tabular}

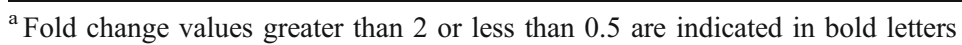

${ }^{\mathrm{b}}$ Induction by $\mathrm{Cd}$ was confirmed by semi-quantitative reverse transcription PCR (Supplemental Fig. 1)

conditions) into 10 clusters (Fig. 3). Clustering allowed us to see the regulation patterns of genes at different time points during $\mathrm{Cd}$ stress in each tissue (root or shoot).

Unexpectedly, the Cd regulation of most of the Cdregulated genes were time point-specific; in other words, most of the genes were regulated under only one of the conditions, although some genes were regulated under more than one condition in cluster 3 (up-regulated from 3 to $48 \mathrm{~h}$ in roots), 5 (up-regulated from $48 \mathrm{~h}$ to 8 days), and 8 (down-regulated from 3 to $48 \mathrm{~h}$ ). In addition, only a few genes were similarly regulated in roots and shoots. These results suggest that gene regulation is dramatically different in the Cd-treated roots and shoots of rice plants.

Based on the gene expression data, rice plants respond to $\mathrm{Cd}$ as follows (Fig. 4). (i) Stress signal transduction is activated by protein kinases, transcription factors, and ROS within a few hours after $\mathrm{Cd}$ exposure mainly in the roots. (ii) Stress-resistance mechanisms involving transporters, chelators, and antioxidants are activated soon after $\mathrm{Cd}$ exposure, mainly in the roots. (iii) The photosynthetic pathways are inactivated soon after $\mathrm{Cd}$ exposure in shoots, whereas in roots, protein synthesis is inactivated, and glycolysis and protein degradation are activated soon after $\mathrm{Cd}$ exposure. These may contribute to the energy and nutrient demands of the stress-resistance mechanisms. (iv) After 8 days of $\mathrm{Cd}$ exposure, Feacquisition mechanisms are activated to restore the Fe homeostasis damaged by $\mathrm{Cd}$.

\section{Stress signal transduction}

The data showed that genes specifically up-regulated in roots during the earliest phase of the response (Cluster 1 in Fig. 3) encoded calcium-dependent protein kinases (CDPKs), mitogen-activated protein kinases (MAPKs), and transcription factors DREB protein, WRKY, NAC, MYB, and AP2. CDPKs and 
Fig. 3 Cluster analysis of 3,596 genes whose expression changed by more than twofold after Cd exposure. Genes were classified in 10 clusters according to the patterns of their regulation of gene expression. The luminosity of the red or green color indicates the intensity of up- or downregulation of each gene under each set of conditions. Gene functions shown in the right half represent those frequently found in each cluster and that are thought to be important in the response to $\mathrm{Cd}$

\section{Root Shoot \\ $\begin{array}{lllllllllll}\mathrm{Cd} 10 & 1 & 1 & 1 & 1 & 10 & 1 & 1 & 1 & 1 & (\mu \mathrm{M})\end{array}$ \\ $3 \mathrm{~h} 1 \mathrm{~d} 2 \mathrm{~d} 3 \mathrm{~d} 8 \mathrm{~d} 3 \mathrm{~h} 1 \mathrm{~d} 2 \mathrm{~d} 3 \mathrm{~d} 8 \mathrm{~d}$}

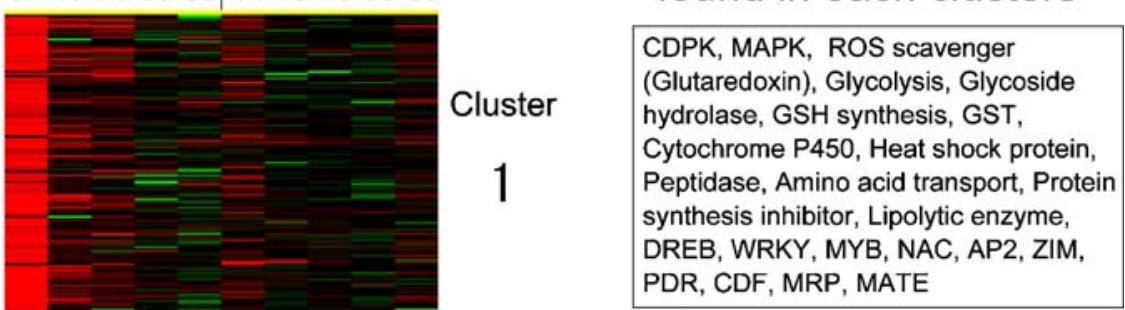

OsHMA5, Ammonium transporter, Fatty acid desaturase, Thioredoxin

Chitinase, $\beta$-1,3-glucanase, GST, Octadecanoid pathway, Cytochrome P450, Peroxidase, MDR, OsIRT1

MFS, Monosaccharide transporter, Metacaspase

Fatty acid desaturase, SAM dependent carboxyl methyltransferase

\section{Lectin, OsHMA2}

Universal stress protein (Usp) family, MYB, Dormancy-associated protein, TGF-beta receptor

Disease resistance protein, Lipolytic enzyme, UDP-glucosyltransferase, Metallothionein, Remorin, Glycolate oxidase, Citrate transporter, Ribosomal proteins

Chlorophyll binding protein, Chlorophyll synthesis, Photosystem I/II subunit, CONSTANS-like protein,

Lipolytic enzyme, Peroxidase, Glycoside hydrolase, Peptidase, Remorin, Polygalacturonase,

Thaumatin-like protein,

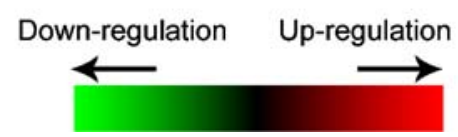

MAPKs are involved in biotic and abiotic stress responses controlling the activation of defense mechanisms (Sheen 1996; Kovtun et al. 2000). The MAPK and CDPK pathways are thought to engage in cross talk with ROS production activities (Ren et al. 2002; Kobayashi et al. 2007). The expression of some genes belonging to the WRKY, NAC, MYB, and AP2 families are reported to be induced by biotic and abiotic stresses, and to play a role in the tolerance to those stresses. Expression of some of them is reported to be enhanced by ROS (Vandenabeele et al. 2003). Therefore, signal transduction involving ROS under biotic and abiotic stresses is suggested to also function in Cd stress. 


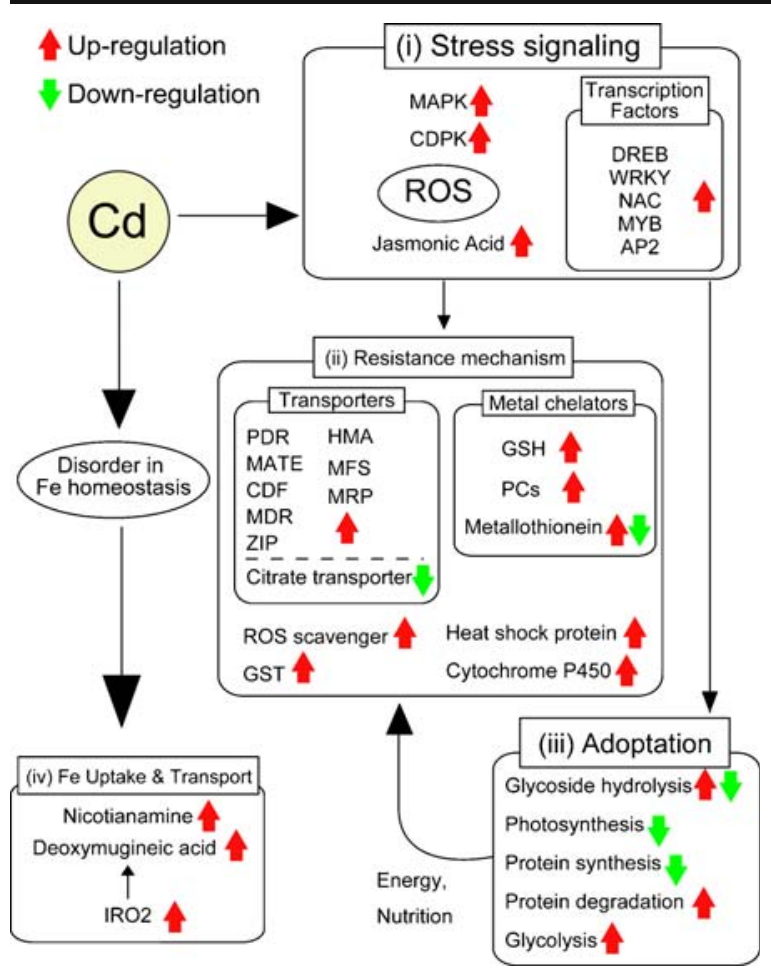

Fig. 4 The response to $\mathrm{Cd}$ in rice as deduced by gene expression. Red or green arrows indicate up- or down-regulated genes, respectively

\section{Stress-resistance mechanism}

Many kinds of stress-resistance mechanisms appeared to be up-regulated in roots soon after the initiation of $\mathrm{Cd}$ stress. For example, transporter genes belonging to transporter families such as PDR and MATE, genes for enzymes that may be involved in GSH synthesis (including those involved in cysteine, glutamate, and glycine, e.g., cysteine synthase, ATP sulfurylase, NADH-dependent glutamate synthase, serine hydroxymethyltransferase, and glutathione synthetase), genes for GST, heat shock proteins, cytochrome $\mathrm{P} 450$, and antioxidants such as glutaredoxin and thioredoxin were up-regulated (Cluster 1 and 2 in Fig. 3). GST has a role in the removal of ROS and also in the conjugation of toxic compounds with GSH because GSH also functions as a chelator. GSHconjugated $\mathrm{Cd}$ is less toxic than $\mathrm{Cd}$ per se, and in yeast, it is exported to the vacuole where $\mathrm{Cd}$ is less toxic to the cell.

As Cd causes oxidative stress to cells (RomeroPuertas et al. 1999; Dixit et al. 2001; Romero-Puertas et al. 2002), scavenging of ROS is important for the detoxification of $\mathrm{Cd}$. Although ROS have a role in signal transduction for stress recognition, their production should be tightly regulated, or damage to the cells will result. Glutaredoxin, thioredoxin, and GSH may be responsible for such regulation by removing ROS in rice under Cd stress.

Activation or inactivation of metabolism, which leads to more efficient energy use and contributes

to stress-resistance mechanisms

Genes involved in the photosynthetic pathways were down-regulated, probably to avoid acceleration of oxidative damage because these pathways are major sources of ROS (Cluster 9 in Fig. 3). The inactivation of photosynthetic pathways is thought to liberate nutrient assimilates that become available for the synthesis of proteins involved in $\mathrm{Cd}$ resistance.

Down-regulation of many genes for ribosomal proteins suggests that protein synthesis, which is a major consumer of ATP and nutrients, is inactivated (Cluster 8 in Fig. 3). This may also liberate nutrient assimilates and contribute to Cd-resistant proteins. In addition, protein degradation is activated by the upregulation of genes for peptidases, which leads to nutrient recycling for the synthesis of Cd-resistant proteins (Cluster 1 in Fig. 3).

Up-regulation of genes involved in glycolysis, the pentose-phosphate pathway, and the tricarboxylic acid cycle by $\mathrm{Cd}$ stress, also reported to occur in Arabidopsis (Sarry et al. 2006), might be necessary to meet the demand for energy and reducing molecules present as, for example, ATP, NADH, and NADPH in Cd-resistance mechanisms (Cluster 1 in Fig. 3).

\section{Fe-acquisition mechanisms}

After 8 days of $\mathrm{Cd}$ exposure in roots, the expression of genes involved in the synthesis of nicotianamine (NA) and 2'-deoxymugineic acid (DMA), which are chelators of heavy metals were up-regulated nearly twofold. These genes include NA synthase genes (OsNAS1, OsNAS2, and OsNAS3) and the DMA synthetase gene (OSDMAS1). In addition, genes involved in the methionine cycle (Fig. 5) (Kobayashi et al. 2005) and the Fe-deficiency-responsive transcription factor OsIRO2 gene (2.93 fold up- 


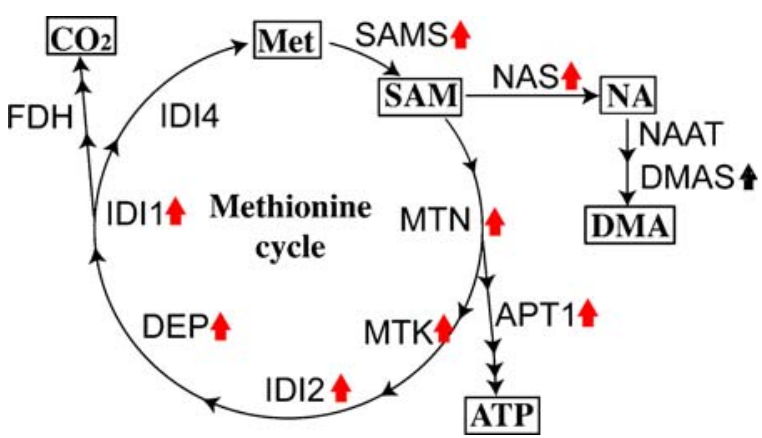

Fig. 5 The biosynthetic pathway of MAs and the methionine cycle in rice. Red arrows indicate up-regulation of the proteins under $\mathrm{Cd}$ stress. NA, nicotianamine; DMA, 2'deoxymugineic acid; Met, methionine; SAM, S-adenosylMet; SAMS, SAM synthetase; NAS, NA synthase; NAAT, NA aminotransferase; DMAS, DMA synthase; MTN, methylthioadenosine/S-adenosyl homocysteine nucleosidase; MTK, methylthioribose kinase; IDI2, eukaryotic initiation factor 2B-like methylthioribose-1-phosphate isomerase; DEP, methylthioribulose-1-phosphate dehydratase-enolasephosphatase; IDI1, 2-keto-methylthiobutyric-acid-forming enzyme; IDI4, putative aminotransferase catalyzing the synthesis of Met from 2-keto-methylthiobutyric acid; FDH, formate dehydrogenase; APT, adenine phosphoribosyltransferase

regulation) were also up-regulated after 8 days of $\mathrm{Cd}$ exposure. These results and the fact that the longer-term $\mathrm{Cd}$ stress worsened the effect on leaf chlorophyll content (Fig. 1b) suggest that $\mathrm{Fe}$ availability is affected after longer periods of $\mathrm{Cd}$ stress.

Comparison of gene regulation between rice and Arabidopsis under Cd stress, or other abiotic stresses in rice

As a comparative analysis of gene regulation in different species is useful for discovering important genes, we compared our data with the data on $\mathrm{Cd}$ stress in Arabidopsis reported by Herbette et al. (2006). In addition, we compared the results of gene regulation by other abiotic stresses (drought, cold, salt, or ABA) reported by Rabbani et al. (2003). Supplemental Table 1 summarizes the rice genes and their orthologs in Arabidopsis that were similarly up- or down-regulated in both species, or under certain stresses. Many orthologs up- or downregulated in Arabidopsis were also similarly up- or down-regulated in rice. For example, similarities were observed in the down-regulation of genes involved in photosynthesis and cell expansion, although the down-regulation of cell expansion in rice occurred after only $3 \mathrm{~h}$ in roots and 8 days in shoots, unlike in Arabidopsis. Down-regulation of cell expansion may contribute to $\mathrm{Cd}$ resistance through rigidification of plant cell walls. Cell wall structure has been said to be strengthened under stress conditions through rigidification to reduce plant growth (Braam et al. 1997; Lu and Neumann 1998). In addition, the metal-binding properties of the cell wall are proposed to be related to metal tolerance (Hall 2002).

Genes involved in the biosynthesis of jasmonic acid were up-regulated in both rice and Arabidopsis. These data indicate that this pathway is important in signal transduction under $\mathrm{Cd}$ stress in both plant species.

$\mathrm{Cd}$ causes oxidative stress to cells, which is also true for other abiotic stresses such as drought, salt, cold, and ABA. Therefore, some similarities in gene regulation may exist among these stress responses. Some genes showed common up-regulation in roots among $\mathrm{Cd}$ and other abiotic stresses, suggesting common regulatory pathways of genes and stress defense mechanisms among these stress responses. Genes up-regulated in roots under $\mathrm{Cd}$ stress for $3 \mathrm{~h}$ include those for carbohydrate metabolism-related enzymes (isocitrate lyase and phosphorylmutase family protein, UDP glucose 4-epimerase-like protein, trehalose-6-phosphate phosphatase, and pyruvate dehydrogenase kinase isoform), the aldehyde dehydrogenase family protein, thioredoxin, and regulatory proteins, that is, proteins involved in signal transduction or the regulation of gene expression (e.g., zinc finger, bZIP, NAC, WRKY, and protein kinase/ phosphatase). These genes may be involved in tolerance to a wide variety of abiotic stresses. For example, the up-regulation of carbohydrate metabolism-related enzymes may contribute to reducing molecules and producing energy and various kinds of sugars, facilitating the regulation of osmotic pressure.

Acknowledgments We thank Dr. Yoshiaki Nagamura of the Rice Genome Project and the NIAS DNA Bank (National Institute of Agrobiological Sciences, Tsukuba, Japan) for support with the $22 \mathrm{~K}$ oligo array analysis. This work was supported by the Program for the Promotion of Basic Research Activities for Innovative Biosciences (PROBRAIN) and a grant from the Ministry of Agriculture, Forestry, and Fisheries of Japan (Genomics for Agricultural Innovation, GMB0001). 
Open Access This article is distributed under the terms of the Creative Commons Attribution Noncommercial License which permits any noncommercial use, distribution, and reproduction in any medium, provided the original author(s) and source are credited.

\section{References}

Achard-Joris M, van den Berg van Saparoea HB, Driessen AJ, Bourdineaud JP (2005) Heterologously expressed bacterial and human multidrug resistance proteins confer cadmium resistance to Escherichia coli. Biochemistry 44:5916-5922

Arao T, Ae N (2003) Genotypic variations in cadmium levels of rice grains. Soil Sci Plant Nutr 49:473-479

Arao T, Ae N, Sugiyama M, Takahashi M (2003) Genotypic differences in cadmium uptake and distribution in soybeans. Plant Soil 251:247-253

Benavides MP, Gallego SM, Tomaro ML (2005) Cadmium toxicity in plants. Braz J Plant Physiol 17:21-34

Bert V, MacNair MR, de Laguerie P, Saumitou-Laprade P, Petit D (2000) Zinc tolerance and accumulation in metallicolous and nonmetallicolous populations of Arabidopsis halleri (Brassicaceae). New Phytol 146:225-233

Bovet L, Eggmann T, Meylan-Bettex M, Polier J, Kammer P, Marin E et al (2003) Transcript levels of AtMRPs after cadmium treatment: induction of AtMRP3. Plant Cell Environ 26:371-381

Braam J, Sistrunk ML, Polisensky DH, Xu W, Purugganan MM, Antosiewicz DM et al (1997) Plant responses to environmental stress: regulation and functions of the Arabidopsis TCH genes. Planta 203(Suppl):S35-S41

Clemens S, Palmgren MG, Krämer U (2002) A long way ahead: understanding and engineering plant metal accumulation. Trends Plant Sci 7:309-315

Cobbett CS, May MJ, Howden R, Rolls B (1998) The glutathione-deficient, cadmium-sensitive mutant, cad2-1, of Arabidopsis thaliana is deficient in $\gamma$-glutamylcysteine synthetase. Plant J 16:73-78

Dixit V, Pandey V, Shyam R (2001) Differential antioxidative responses to cadmium in roots and leaves of pea (Pisum sativum L. cv. Azad). J Exp Bot 52:1101-1109

Dubouzet JG, Sakuma Y, Ito Y, Kasuga M, Dubouzet EG, Miura S et al (2003) OsDREB genes in rice, Oryza sativa L., encode transcription activators that function in drought-, high-saltand cold-responsive gene expression. Plant J 33:751-763

Eren E, Argüello JM (2004) Arabidopsis HMA2, a divalent heavy metal-transporting $\mathrm{P}_{\mathrm{IB}^{\mathrm{B}}}$-type ATPase, is involved in cytoplasmic $\mathrm{Zn}^{2+}$ homeostasis. Plant Physiol 136:3712-3723

Fujita M, Fujita Y, Maruyama K, Seki M, Hiratsu K, Ohme-Takagi $\mathrm{M}$ et al (2004) A dehydration-induced NAC protein, RD26, is involved in a novel ABA-dependent stress-signaling pathway. Plant J 39:863-876

Fusco N, Micheletto L, Dal Corso G, Borgato L, Furini A (2005) Identification of cadmium-regulated genes by cDNA-AFLP in the heavy metal accumulator Brassica juncea L. J Exp Bot 56:3017-3027

Gong JM, Lee DA, Schroeder J (2003) Long-distance root-toshoot transport of phytochelatins and cadmium in Arabidopsis. Proc Natl Acad Sci USA 100:10118-10123
Gravot A, Lieutaud A, Verret F, Auroy P, Vavasseur A, Richaud $\mathrm{P}$ (2004) AtHMA3, a plant $\mathrm{P}_{1 \mathrm{~B}}$-ATPase, functions as a $\mathrm{Cd} /$ $\mathrm{Pb}$ transporter in yeast. FEBS Lett 561:22-28

Grill E, Winnacker EL, Zenk MH (1985) Phytochelatins: the principal heavy-metal complexing peptides of higher plants. Science 230:674-676

Grotz N, Fox T, Connolly E, Park W, Guerinot ML, Eide D (1998) Identification of a family of zinc transporter genes from Arabidopsis that respond to zinc deficiency. Proc Natl Acad Sci USA 95:7220-7224

Hall JL (2002) Cellular mechanisms for heavy metal detoxification and tolerance. J Exp Bot 53:1-11

Herbette S, Taconnat L, Hugouvieux V, Piette L, Magniette MLM, Cuine S et al (2006) Genome-wide transcriptome profiling of the early cadmium response of Arabidopsis roots and shoots. Biochimie 88:1751-1765

Howden R, Andersen CR, Goldsbrough PB, Cobbett CS (1995a) A cadmium-sensitive, glutathione-deficient mutant of Arabidopsis thaliana. Plant Physiol 107:10671073

Howden R, Goldsbrough PB, Andersen CR, Cobbett CS (1995b) Cadmium-sensitive, cad1 mutants of Arabidopsis thaliana are phytochelatin deficient. Plant Physiol 107:1059-1066

Ishikawa S, Ae N, Sugiyama M, Murakami M, Arao T (2005) Genotypic variation in shoot cadmium concentration in rice and soybean in soils with different levels of cadmium contamination. Soil Sci Plant Nutr 51:101-108

Kikuchi T, Okazaki M, Toyota K, Motobayashi T, Kato M (2007) The input-output balance of cadmium in a paddy field of Tokyo. Chemosphere 67:920-927

Kim DY, Bovet L, Maeshima M, Martinoia E, Lee Y (2007) The ABC transporter AtPDR8 is a cadmium extrusion pump conferring heavy metal resistance. Plant J 50:207218

Kobayashi T, Suzuki M, Inoue H, Itai RN, Takahashi M, Nakanishi $\mathrm{H}$ et al (2005) Expression of iron-acquisitionrelated genes in iron-deficient rice is co-ordinately induced by partially conserved iron-deficiency-responsive elements. J Exp Bot 56:1305-1316

Kobayashi M, Ohura I, Kawakita K, Yokota N, Fujiwara M, Shimamoto $\mathrm{K}$ et al (2007) Calcium-dependent protein kinases regulate the production of reactive oxygen species by potato NADPH oxidase. Plant Cell 19:1065-1080

Korshunova YO, Eide D, Clark WG, Guerinot ML, Pakrasi HB (1999) The IRT1 protein from Arabidopsis thaliana is a metal transporter with a broad substrate range. Plant Mol Biol 40:37-44

Kovtun Y, Chiu WL, Tena G, Sheen J (2000) Functional analysis of oxidative stress-activated mitogen-activated protein kinase cascade in plants. Proc Natl Acad Sci USA 97:29402945

Li ZS, Lu YP, Zhen RG, Szczypka M, Thiele DJ, Rea PA (1997) A new pathway for vacuolar cadmium sequestration in Saccharomyces cerevisiae: YCF1-catalyzed transport of bis(glutathionato)cadmium. Proc Natl Acad Sci USA 94:42-47

Li L, He Z, Pandey GK, Tsuchiya T, Luan S (2002) Functional cloning and characterization of a plant efflux carrier for multidrug and heavy metal detoxification. J Biol Chem 277:5360-5368 
Lu Z, Neumann PM (1998) Water-stressed maize, barley and rice seedlings show species diversity in mechanisms of leaf growth inhibition. J Exp Bot 49:1945-1952

McGrath SP, Zhao FJ, Lombi E (2001) Plant and rhizosphere processes involved in phytoremediation of metalcontaminated soils. Plant Soil 232:207-214

Mills R, Francini A, Ferreiradarocha P, Baccarini P, Aylett M, Krijger $\mathrm{G}$ et al (2005) The plant $\mathrm{P}_{1 \mathrm{~B}}$-type ATPase AtHMA4 transports $\mathrm{Zn}$ and $\mathrm{Cd}$ and plays a role in detoxification of transition metals supplied at elevated levels. FEBS Lett 579:783-791

Momose Y, Iwahashi H (2001) Bioassay of cadmium using a DNA microarray: Genome-wide expression patterns of Saccharomyces cerevisiae response to cadmium. Environ Toxicol Chem 20:2353-2360

Murakami M, Ae N, Ishikawa S, Ibaraki T, Ito M (2008) Phytoextraction by a high-Cd-accumulating rice: reduction of Cd content of soybean seeds. Environ Sci Technol 42:6167-6172

Nakanishi H, Ogawa I, Ishimaru Y, Mori S, Nishizawa NK (2006) Iron deficiency enhances cadmium uptake and translocation mediated by the $\mathrm{Fe}^{2+}$ transporters OsIRT1 and OsIRT2 in rice. Soil Sci Plant Nutr 52:464-469

Pence NS, Larsen PB, Ebbs SD, Letham DL, Lasat MM, Garvin DF et al (2000) The molecular physiology of heavy metal transport in the $\mathrm{Zn} / \mathrm{Cd}$ hyperaccumulator Thlaspi caerulescens. Proc Natl Acad Sci USA 97:4956-4960

Rabbani MA, Maruyama K, Abe H, Khan MA, Katsura K, Ito $Y$ et al (2003) Monitoring expression profiles of rice genes under cold, drought, and high-salinity stresses and abscisic acid application using cDNA microarray and RNA gelblot analyses. Plant Physiol 133:1755-1767

Ren D, Yang H, Zhang S (2002) Cell death mediated by MAPK is associated with hydrogen peroxide production in Arabidopsis. J Biol Chem 277:559-565

Robinson BH, Leblanc M, Petit D, Brooks RR (1998) The potential of Thlaspi caerulescens for phytoremediation of contaminated soils. Plant Soil 203:47-56

Romero-Puertas MC, McCarthy I, Sandalio LM, Palma JM, Corpas FJ, Gómez M et al. (1999) Cadmium toxicity and oxidative metabolism of pea leaf peroxisomes. Free Radic Res Suppl:S25-S31

Romero-Puertas MC, Palma JM, Gómez M, del Río LA, Sandalio LM (2002) Cadmium causes the oxidative modification of proteins in pea plants. Plant Cell Environ 25:677-686

Romero-Puertas MC, Rodriguez-Serrano M, Corpas FJ, Gomez M, Del Rio LA, Sandalio LM (2004) Cadmium-induced subcellular accumulation of $\mathrm{O}_{2}-$ and $\mathrm{H}_{2} \mathrm{O}_{2}$ in pea leaves. Plant Cell Environ 27:1122-1134
Sandalio LM, Dalurzo HC, Gómez M, Romero-Puertas MC, del Río LA (2001) Cadmium-induced changes in the growth and oxidative metabolism of pea plants. J Exp Bot 52:2115-2126

Sanità di Toppi L, Gabbrielli R (1999) Response to cadmium in higher plants. Environ Exp Bot 41:105-130

Sarry JE, Kuhn L, Ducruix C, Lafaye A, Junot C, Hugouvieux V et al (2006) The early responses of Arabidopsis thaliana cells to cadmium exposure explored by protein and metabolite profiling analyses. Proteomics 6:2180-2198

Thomine Sb, Wang R, Ward JM, Crawford NM, Schroeder J (2000) Cadmium and iron transport by members of a plant metal transporter family in Arabidopsis with homology to Nramp genes. Proc Natl Acad Sci USA 97:4991-4996

Sheen J (1996) $\mathrm{Ca}^{2+}$-dependent protein kinases and stress signal transduction in plants. Science 274:1900-1902

Stohs SJ, Bagchi D (1995) Oxidative mechanisms in the toxicity of metal ions. Free Radic Biol Med 18:321-336

Suzuki N, Koizumi N, Sano H (2001) Screening of cadmiumresponsive genes in Arabidopsis thaliana. Plant Cell Environ 24:1177-1188

Tommasini R, Vogt E, Fromenteau M, Hörtensteiner S, Matile P, Amrhein N et al (1998) An ABC-transporter of Arabidopsis thaliana has both glutathione-conjugate and chlorophyll catabolite transport activity. Plant J 13:773780

Vandenabeele S, Van Der Kelen K, Dat J, Gadjev I, Boonefaes T, Morsa S et al (2003) A comprehensive analysis of hydrogen peroxide-induced gene expression in tobacco. Proc Natl Acad Sci USA 100:16113-16118

Verret F, Gravot A, Auroy P, Leonhardt N, David P, Nussaume L et al (2004) Overexpression of AtHMA4 enhances rootto-shoot translocation of zinc and cadmium and plant metal tolerance. FEBS Lett 576:306-312

Vido K, Spector D, Lagniel G, Lopez S, Toledano MB, Labarre J (2001) A proteome analysis of the cadmium response in Saccharomyces cerevisiae. J Biol Chem 276:8469-8474

Vierling E (1991) The roles of heat shock proteins in plants. Annu Rev Plant Physiol Plant Mol Biol 42:579-620

Xie Q, Sanz-Burgos AP, Guo H, García JA, Gutiérrez C (1999) GRAB proteins, novel members of the NAC domain family, isolated by their interaction with a geminivirus protein. Plant Mol Biol 39:647-656

Yepiskoposyan H, Egli D, Fergestad T, Selvaraj A, Treiber C, Multhaup G et al (2006) Transcriptome response to heavy metal stress in Drosophila reveals a new zinc transporter that confers resistance to zinc. Nucleic Acids Res $34: 4866-4877$ 